\title{
A FURTHER STUDY OF THE UTILIZATION OF DIETARY GLYCINE NITROGEN FOR URIC ACID SYNTHESIS IN GOUT ${ }^{1}$
}

\author{
By JEAN D. BENEDICT, T. F. YU, EDWARD J. BIEN, ALEXANDER B. GUTMAN \\ AND DEWITT STETTEN, JR. \\ (From the Division of Nutrition and Physiology, the Public Health Research Institute of the \\ City of New York, New York; Department of Medicine, The Mount Sinai \\ Hospital, New York)
}

(Submitted for publication January 15, 1953; accepted May 1, 1953)

In an earlier report (1) an experiment was described in which a test dose of glycine- $\mathrm{N}^{15}$ was fed to a gouty subject and the abundance of $\mathrm{N}^{15}$ in uric acid as well as in other urinary constituents was measured for several days. It was found that three times as much of the administered $\mathrm{N}^{15}$ could be recovered in urinary uric acid in the gouty subject as in the two normal subjects studied.

The gouty subject used in this initial study had been deliberately selected on the basis of his excessive basal urinary uric acid excretion in order to determine whether increased basal urinary excretion of uric acid, which has been found to occur in about 25 per cent of all gouty subjects studied (2), can properly be ascribed to overproduction of uric acid. In the present report are included similar experiments on three further gouty subjects, one also excreting excessive quantities of uric acid in the urine, the other two excreting amounts within the normal range under the prescribed dietary conditions.

\section{METHODS AND MATERIALS}

All subjects were maintained on a constant low purine, restricted protein diet (Table I) for 5 to 10 days before administration of glycine and thereafter throughout the period of urine collections. Estimations of urinary excretion of uric acid and total nitrogen were made during the preliminary and experimental periods.

Isotopic glycine ( $\mathrm{N}^{15}=60.5$ atom per cent excess) was fed with breakfast to each subject at a dosage level of $100 \mathrm{mg}$. per $\mathrm{Kg}$. of body weight. All synthetic, isolation and analytical procedures were conducted precisely as in the earlier experiment. In one subject (A. R.) the magnitude and turnover rate of the miscible pool of uric acid were determined (3) following intravenous injection of $100 \mathrm{mg}$. of uric acid-1, 3-N $\mathrm{N}^{15}$.

1 This work was carried out with the support of a grant-in-aid from the National Institute of Arthritis and Metabolic Diseases, National Institutes of Health.

\section{Subjects}

The gouty subjects selected for study all had unequivocal evidence of the disease, were in about the same (relatively young) age group, had about the same duration of clinical symptoms with similar course, and could not be differentiated on clinical grounds. The one significantly different finding was that $H$. G. and D. R. consistently excreted unequivocally greater than normal amounts of uric acid in the urine on the indicated diet whereas the urinary urate excretion of A. R. and J. R. consistently remained within normal limits (Table $I$ ).

The normal subjects, E. B. and M. R. were described in an earlier report (1). The clinical history of gouty subject D. R. also has been described (1).

H. G., a 38 year old white male, had his first attack of gout at the age of 25 . In the past 13 years, acute attacks were never frequent but increased in severity. His mother was stated to have arthritis, but there is no family history of gout. A small tophus in one ear and a punchedout area seen on $\mathrm{X}$-ray at the first left metatarsal joint have been noted. Routine urinalysis was normal; serum NPN, $34 \mathrm{mg}$. per $100 \mathrm{ml}$; inulin clearance, $117 \mathrm{ml}$. per min. ( $91.5 \mathrm{ml}$. per min. after correction for surface area); serum uric acid, 10.0 to $12.0 \mathrm{mg}$. per $100 \mathrm{ml}$.

A. R., a 42 year old white male, had his first attack of acute gout at 34 . Acute attacks have increased in frequency, occurring weekly or fortnightly prior to November, 1950. He has been on a regimen of colchicine prophylaxis since that time. There are no superficial tophi, but X-ray reveals punched-out areas at the bases of both great toes. Routine urinalysis was normal; serum NPN, 30 to $35 \mathrm{mg}$. per $100 \mathrm{ml}$.; PSP excretion, 80 per cent after 2 hours; inulin clearance, $100 \mathrm{ml}$. per min. (88.2 ml. per min. after correction for surface area); serum uric acid 9.0 to $10.0 \mathrm{mg}$. per $100 \mathrm{ml}$.

J. R., a 40 year old white male, had his first attack of gout at age 31 . The maternal grandfather and two of nine siblings have had gout. Both parents and five siblings have hyperuricemia. Colchicine was of benefit both therapeutically and prophylactically. No tophi have been found, nor is there evidence of tophaceous deposits on X-ray examination. Routine urinalysis was normal; blood urea nitrogen, $16 \mathrm{mg}$. per $100 \mathrm{ml}$; inulin clearance, $98.5 \mathrm{ml}$. per min. (87.7 $\mathrm{ml}$. per min. after correction for surface area); serum uric acid, 8.5 to $10.0 \mathrm{mg}$. per $100 \mathrm{ml}$. 


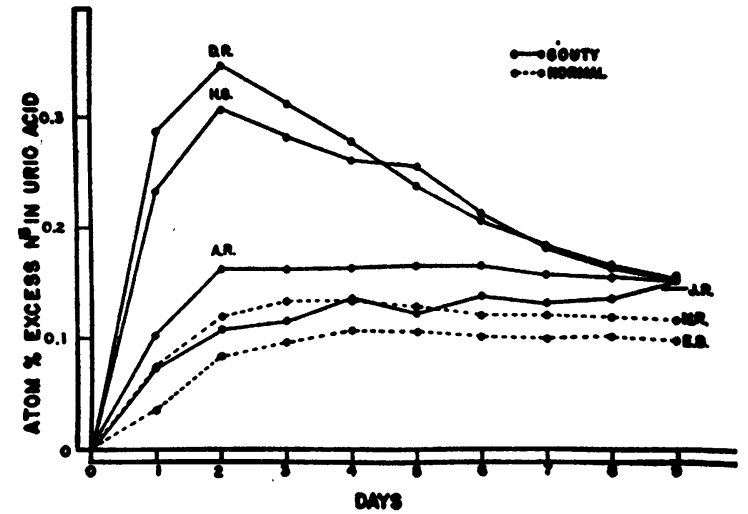

Fig. 1. The Abundance of $\mathrm{N}^{16}$ in Daily Urinary Uric Acid from Four Gouty aNd Two Normal SUBJECTS

The concentration of $\mathrm{N}^{25}$ as atom per cent excess has been plotted against time in days.

\section{RESULTS AND DISCUSSION}

The concentrations of $\mathrm{N}^{15}$ in urinary uric acid following the ingestion of a single test dose of glycine- $\mathrm{N}^{15}$ are plotted as a function of time in Figure 1. In two of the gouty subjects, D. R. and H. G., far higher concentrations of isotope are found than in the normal control experiments (M. R. and E. B.) ; the initial rise is more rapid as is also the subsequent decline in $\mathrm{N}^{15}$ abundance. Maxima are obtained in these two cases on the second day, where in the normals, maxima appear on the third or fourth day. Subject A. R. excreted uric acid which may be somewhat more enriched with $\mathrm{N}^{15}$ than normal. Subject J. R., on the other

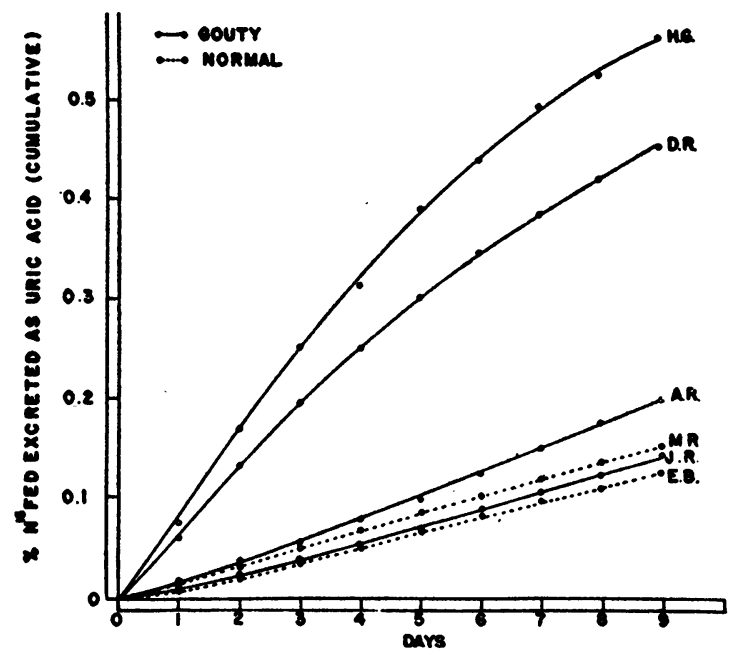

Fig. 2. The Excretion of $\mathrm{N}^{\text {ws }}$ as Uric Acid by Four Gouty and Two Normal Subjects

The per cent of the total dose of administered $\mathrm{N}^{15}$ which was excreted has been plotted cumulatively.

hand, gave normal values for the first few days after feeding of glycine- $\mathrm{N}^{15}$ but, in contrast to the normal subjects, the uric acid excreted by this subject continued to show progressive enrichment with $\mathrm{N}^{18}$ up to the ninth day. The experiment upon this last subject was repeated and essentially superimposable data were obtained.

From the quantity of $\mathrm{N}^{15}$ fed, the quantity of uric acid excreted in each day's urine and the $\mathrm{N}^{15}$ concentration in this uric acid, the percentage of the administered dose of $\mathrm{N}^{15}$ excreted as uric acid has been calculated and this information is plotted

TABLE I

Per cent of dose of administered $N^{15}$ excreted as uric acid and as total nitrogen over a nine day period

\begin{tabular}{|c|c|c|c|c|c|c|c|c|c|c|}
\hline \multirow[b]{2}{*}{ Case } & \multirow[b]{2}{*}{$\begin{array}{l}\text { Wt. } \\
\text { kg. }\end{array}$} & \multicolumn{5}{|c|}{ Daily dietary intake* } & \multicolumn{2}{|c|}{ Daily excretion } & \multicolumn{2}{|c|}{$\begin{array}{l}\text { Per cent of Nis fed } \\
\text { excreted as }\end{array}$} \\
\hline & & $\frac{\text { Pro }}{\text { g. }}$ & $\frac{\text { tein }}{\text { g./kg. }}$ & $\begin{array}{l}\text { Fat } \\
\text { g. }\end{array}$ & $\mathrm{COH}_{8 .}$ & Calories & $\begin{array}{l}\text { Total N } \\
\text { g. }\end{array}$ & $\begin{array}{l}\text { Uric acid N } \\
\text { mg. }\end{array}$ & Total $\mathbf{N}$ & Uric acid $\mathrm{N}$ \\
\hline $\begin{array}{l}\text { Normal } \\
\text { E. B.† } \\
\text { M. R.† }\end{array}$ & $\begin{array}{l}76 \\
80\end{array}$ & $\begin{array}{l}48 \\
80\end{array}$ & $\begin{array}{r}0.6 \\
-1.0\end{array}$ & & & & $\begin{array}{r}7.6 \pm 0.5 \ddagger \\
11.1 \pm 0.8\end{array}$ & $\begin{array}{l}131 \pm 48 \\
159 \pm 8\end{array}$ & $\begin{array}{l}33.0 \\
45.4\end{array}$ & $\begin{array}{l}0.125 \\
0.153\end{array}$ \\
\hline $\begin{array}{l}\text { Gouty } \\
\text { H. G. } \\
\text { D. R. } \dagger \\
\text { A. R. } \\
\text { J. R. (1) } \\
\text { J. R. (2) }\end{array}$ & $\begin{array}{l}104 \\
90 \\
85.5 \\
84.5 \\
89\end{array}$ & $\begin{array}{l}75 \\
68 \\
50 \\
59 \\
74\end{array}$ & $\begin{array}{l}0.7 \\
0.8 \\
0.6 \\
0.7 \\
0.8\end{array}$ & $\begin{array}{l}45 \\
67 \\
70 \\
67 \\
65\end{array}$ & $\begin{array}{l}580 \\
340 \\
205 \\
200 \\
205\end{array}$ & $\begin{array}{l}3,025 \\
2,235 \\
1,645 \\
1,640 \\
1,700\end{array}$ & $\begin{array}{r}11.9 \pm 1.0 \\
10.8 \pm 0.4 \\
8.0 \pm 0.4 \\
9.4 \pm 0.2 \\
11.8 \pm 0.7\end{array}$ & $\begin{array}{l}334 \pm 36 \\
228 \pm 6 \\
144 \pm 14 \\
131 \pm 5 \\
134 \pm 10\end{array}$ & $\begin{array}{l}50.9 \\
44.6 \\
39.7 \\
41.2 \\
46.5\end{array}$ & $\begin{array}{l}0.563 \\
0.453 \\
0.198 \\
0.142 \\
0.130\end{array}$ \\
\hline
\end{tabular}

* Diet limited to cereals and other grain products, milk and milk products, eggs, non-leguminous vegetables and fruits; no meats, fish or fowl.

†rom previous report (1).

$\ddagger$ Average deviation.

Mean urinary uric acid $N$ excretion of 13 normal subjects on basal diet: $139 \pm 23 \mathrm{mg}$. per $24 \mathrm{hr}$. 
cumulatively in Figure 2. It will be seen that at all times gouty subjects H. G. and D. R. had eliminated a larger fraction of administered glycine nitrogen as uric acid than had the normal subjects. Subject A. R. certainly did not deviate markedly from normal in this regard, whereas subject $J$. R. appears to fall within the normal range.

In Table $I$ are given the results of accumulated excretions over the nine-day period following feeding of glycine- $\mathrm{N}^{15}$. The normal subjects excreted 0.12 to 0.15 per cent of the ingested $\mathrm{N}^{15}$ as uric acid in this time interval. Subject J. R., studied on two occasions, excreted 0.13 to 0.14 per cent, whereas subject $A$. $R$. excreted 0.20 per cent of administered glycine nitrogen as uric acid. A far higher fraction, three to four times normal, was found in the two subjects $H$. G. and D. R., who excreted 0.56 and 0.45 per cent, respectively, of dietary glycine nitrogen as urinary uric acid.

In two of the patients studied (H. G. and D. R.) there is unequivocal evidence for abnormally rapid incorporation of dietary glycine nitrogen into uric acid. In the remaining two patients this effect is either unimpressive or absent. A good rank order correlation is to be noted between the daily excretion of uric acid in the urine and the per cent of ingested isotope appearing in urinary uric acid (see Table I). It would seem as though patients suffering from gout may crudely be divided into two types, those who synthesize uric acid abnormally rapidly and, given normal renal function, are prone to excrete large amounts of uric acid in the urine, and those who are within normal limits in these two regards. Muller and Bauer have recently described a case belonging to the latter category (4). Whether this difference results from an actual difference in the pathological process or whether it represents the same process at different stages remains to be determined.

The possibility was entertained that the gouty patients whose uric acid was not isotopically enriched above that of the normal subject might also be overproducing uric acid. Such overproduction might not be apparent in the isotope values if the miscible pool of uric acid were excessively large. A very large miscible pool of preformed uric acid would dilute the isotope in the newly synthesized uric acid. The magnitude of the miscible pool of uric acid in patient A. R. has therefore been determined (3) and was found to be $1,500 \mathrm{mg}$. (normal value, about $1,100 \mathrm{mg}$.). This value was not considered to deviate sufficiently from normal to permit the conclusion that any impressive overproduction of uric acid was occurring in this patient.

\section{SUMMARY}

Glycine- $\mathrm{N}^{15}$ has been fed in a standard experiment to gouty subjects maintained on a purinepoor, restricted protein diet and the excretion of $\mathrm{N}^{15}$ in uric acid has been studied.

In subjects who exhibited abnormally high basal uric acid excretions, an abnormally rapid incorporation of dietary glycine nitrogen into uric acid occurred. In others whose basal excretion was approximately normal, no such evidence of accelerated uric acid synthesis was demonstrable.

The significance of these results is discussed.

\section{ACKNOWLEDGMENTS}

The authors wish to express their indebtedness to Mrs. Eleanor Schroeder and Mr. Frank J. Rennie for assistance in conducting the isotope analyses.

\section{REFERENCES}

1. Benedict, J. D., Roche, M., Yü, T. F., Bien, E. J., Gutman, A. B., and Stetten, D., Jr. Incorporation of glycine nitrogen into uric acid in normal and gouty man. Metabolism 1952, 1, 3.

2. Gutman, A. B., and Yü, T. F., Current principles of management in gout. Am. J. Med., 1952, 13, 744.

3. Benedict, J. D., Forsham, P. H., and Stetten, D., Jr., The metabolism of uric acid in the normal and gouty human studied with the aid of isotopic uric acid. J. Biol. Chem., 1949, 181, 183.

4. Muller, A. F., and Bauer, W., Uric acid production in normal and gouty subjects, determined by $\mathrm{N}^{16}$ labeled glycine. Proc. Soc. Exper. Biol. \& Med., 1953, 82, 47. 